\title{
Nest-dwelling ectoparasites of two sympatric hole-nesting passerines in relation to nest composition: An experimental study ${ }^{1}$
}

\author{
Juan MORENO², Santiago MERINO, Elisa LOBATO, Rafael RUIZ-DE-CASTAÑEDA, \\ Josué MARTÍNEZ-DE LA PUENTE, Sara DEL CERRO \\ \& Juan RIVERO-DE AGUILAR, Departamento de Ecología \\ Evolutiva, Museo Nacional de Ciencias Naturales-CSIC, J. Gutiérrez \\ Abascal 2, E-28006 Madrid, Spain.
}

Abstract: There are often marked differences in the incidence of nest-dwelling ectoparasite species on different coexisting and similar avian host species. This has been shown especially for fleas (Siphonaptera), larvae of flies (Diptera), and mites (Acarina) in nests of tits and flycatchers breeding in nest-boxes in close proximity to each other. One of the possible reasons for these differences is the marked differences in nest composition between avian species. We show here differences in ectoparasite presence and nest composition for blue tits (Cyanistes caeruleus) and pied flycatchers (Ficedula hypoleuca) coexisting in oak forests in central Spain. There also may be intraspecific differences in local preferences for nest-building materials according to availability of plant materials, which could be due to arthropod repellent properties of different potential nest components. We show here a local difference in nest composition between 2 pied flycatcher populations in relation to availability of a preferred material associated with higher ectoparasite presence in the locality without the preferred nest material. We test the hypotheses that differential incidence of ectoparasites at the interspecific and intraspecific levels may depend on nest composition. We conducted a nest exchange experiment in one study locality in 2007 placing in nest-boxes occupied by flycatchers 1) nests constructed by blue tits in 2006 in another locality and removed before use and stored frozen, 2) nests constructed by flycatchers in 2006 in another locality with different nest composition and removed before use and stored frozen, and 3) nests constructed by other flycatcher pairs in the same study locality in 2007. Another group of flycatcher nests was kept as pure control, while a few blue tit nests constructed in 2007 and taken over by flycatchers were used for comparison with nests of treatment 1 . No effect on presence of mites and blowflies of either nest-constructing species or locality of construction was observed for pied flycatcher nests, and for fleas only an effect of locality but not of nest constructing species was detected. On the other hand, presence of mites and blowflies differed between nests constructed by blue tits and occupied by either blue tits or pied flycatchers. Nest composition does not explain the differential incidence of nest-dwelling ectoparasites on coexisting avian host species.

Keywords: arthropod ectoparasites, avian host, cavity nesting, ectoparasite fauna, nest construction, nest exchange.

Résumé : Il y a souvent des différences marquées dans la fréquence d'espèces d'ectoparasites de nid chez différentes espèces coexistantes d'hôtes aviaires similaires. Ceci a été démontré particulièrement pour les puces (Siphonaptera), les larves de mouches (Diptera) et les acariens (Acarina) dans des nids de mésanges et de gobemouches dans des nichoirs à proximité les uns des autres. Une des raisons possibles de ces différences est la différence marquée dans la composition du nid entre les espèces d'oiseaux. Nous montrons ici des différences dans la présence d'ectoparasites et dans la composition du nid chez des mésanges bleues (Cyanistes caeruleus) et des gobemouches noirs (Ficedula hypoleuca) coexistants dans des chênaies du centre de l'Espagne. Il peut aussi y avoir des différences intraspécifiques dans les préférences locales de matériel de construction du nid selon la disponibilité du matériel végétal, ces différences pourraient être dues aux propriétés répulsives pour les arthropodes des différentes composantes potentielles des nids. Nous montrons ici une différence locale dans la composition du nid entre 2 populations de gobemouche noir en lien avec la disponibilité d'un matériel préféré et associée à une présence plus élevée d'ectoparasites dans le site dépourvu du matériel de nid préféré. Nous évaluons l'hypothèse que les différences dans la fréquence d’ectoparasites aux niveaux interspécifique et intraspécifique peuvent dépendre de la composition du nid en menant une expérience d'échange de nids en 2007 dans un des sites d'étude en plaçant dans des nichoirs occupés par des gobemouches : 1) des nids construits en 2006 par des mésanges bleues dans un autre site, retirés avant utilisation et entreposés gelés, 2) des nids construits en 2006 par des gobemouches dans un autre site et ayant une composition différente, retirés avant utilisation et entreposés gelés, et 3) des nids construits la même année par d'autres couples de gobemouches du même site. Un autre groupe de nids de gobemouches a été conservé tel quel en tant que pur contrôle, alors que quelques nids construits en 2007 par des mésanges bleues et repris par des gobemouches ont été utilisés pour une comparaison avec les nids du premier traitement. Aucun effet de l'espèce construisant le nid ou du site dans lequel le nid a été construit n’a été observé sur la présence d'acariens et de calliphores dans les nids de gobemouches noirs. Dans le cas des puces, un effet du site a été détecté, mais pas de l'espèce. D'autre part, la présence d'acariens et de calliphores différait entre les nids construits par des mésanges bleues et occupés soit par des mésanges bleues ou des gobemouches noirs. La composition du nid n'explique pas les fréquences différentes d'ectoparasites de nid chez des espèces coexistantes d’hôtes aviaires. Mots-clés : arthropode ectoparasite, cavités de nidification, construction de nid, échange de nid, faune ectoparasite, hôte aviaire. 



\section{Introduction}

Nest-dwelling ectoparasites feeding on the blood of nestlings and adults constitute an important selective force affecting avian life history evolution (Møller, 1997). These ectoparasites may reduce the reproductive success of hosts by reducing nestling growth (Merino \& Potti, 1995) or inducing nest desertion (Oppliger, Richner \& Christe, 1994), and they may even affect parental health (Tomás et al., 2007). For hole-nesters, fleas (Siphonaptera), flies (Diptera), and mites (Acarina) constitute the most important groups of nest-dwelling ectoparasites (e.g., Merino \& Potti, 1995; Rendell \& Verbeek, 1996). Ectoparasite faunas in avian nests differ according to host species, even in conditions of sympatry (Bennett \& Whitworth, 1992; Bauchau, 1998). These differences may depend on interspecific variation in host defences based on parental behaviour, nestling immunity, or nest properties.

Tits and pied flycatchers coexist frequently in European woodlands and present different levels of infestation by different species of ectoparasites (Bauchau, 1998). Thus, Bauchau (1998) found that great tit (Parus major) nests showed higher abundances of mites, fleas, and blowflies than pied flycatcher (Ficedula hypoleuca) nests in the Netherlands, while Remes and Krist (2005) have found the same trend for blowflies between coexisting great tits and collared flycatchers (Ficedula albicollis) in the Czech Republic. One of the factors suggested to explain differences in ectoparasite loads between tits and flycatchers is nest design and composition (Bauchau, 1998; Remes \& Krist, 2005). Nest composition may affect ectoparasite development by modulating larval mortality and growth through effects on nest humidity (Heeb, Kölliker \& Richner, 2000), but it may also determine chemical attraction for dispersing and laying females of different ectoparasite species associated to different plant odours (Remes \& Krist, 2005). Thus, one might suspect $a$ priori that flycatchers and tits differ in parasites due to materials used in nest construction.

Normally, tits build nests mainly of moss and hair, while flycatcher nests are composed of dry grass, bark, and dry leaves (Cramp \& Perrins, 1993). However, the generality of this difference may depend on the populations studied and the availability of nest materials. For instance, it is known that Canary Islands blue tits (Cyanistes teneriffae) do not build nests of moss (del Hoyo, Elliott \& Christie, 2007). In the present study we have aimed at establishing an interspecific difference in nest composition between blue tits (C. caeruleus) and pied flycatchers coexisting in montane oak forests in central Spain. Pied flycatchers and blue tits are small, insectivorous, hole-nesting passerines with similar body mass, breeding season, and habitat that coexist throughout a large part of their range. Moreover, the exact composition of nests at the intraspecific level may depend not only on availability of different vegetation substrates (Hansell, 2000), but also on preferences for certain materials. Such preferences could be related to protection from ectoparasites. Thus, it has been proposed that the bark of different tree and shrub species contains toxic secondary compounds that may have insecticidal properties (Jacobson, 1990; Carroll, 1994). We have detected that pied flycatch- ers prefer the bark of an oil-producing Mediterranean shrub as nest material in one of our study localities, where this shrub is abundant. Moreover, we have observed that they suffer higher ectoparasite infestation in a different locality without the preferred nest material. The generality of the interspecific differences in ectoparasite prevalence found by Bauchau (1998) and Remes and Krist (2005) remains to be confirmed in a different ecological scenario. Here, we have tested for such a difference with 2 species not previously compared, in the southern part of the distribution of both species.

The objectives of this study were to test if differences in ectoparasite prevalence between coexisting bird species and between different populations of the same species can be related to interspecific and intraspecific differences in nest composition. The effect of nest composition on ectoparasite abundances can only be truly estimated through exchanges of nests between species (e.g., Remes \& Krist, 2005). We conducted such an experiment by exchanging pied flycatcher nests for blue tit nests and looking at effects of different nest compositions on ectoparasite abundances in nest-boxes occupied by pied flycatchers. In contrast to Remes and Krist (2005), who concentrated their study on blowflies, we compared infestations of all nest-dwelling ectoparasites known to infest pied flycatcher and blue tit nests in our study locality, namely mites, fleas, and blowflies. We used the opportunity of studying 2 populations of pied flycatchers with different nest compositions to test if preferences for certain nest materials at the intraspecific level may be related to ectoparasite avoidance. To this end, we exchanged pied flycatcher nests of different composition built in different localities.

\section{Methods}

\section{STUDY SPECIES AND LOCALITIES}

The study was conducted in 2006 and 2007 in 2 montane Pyrenean oak (Quercus pyrenaica) forests in central Spain: Valsaín, at $1200 \mathrm{~m}$ elevation $\left(40^{\circ} 53^{\prime} \mathrm{N}, 4^{\circ} 01^{\prime} \mathrm{w}\right)$, and Lozoya, at $1400 \mathrm{~m}$ elevation $\left(40^{\circ} 58^{\prime} \mathrm{N}, 3^{\circ} 48^{\prime} \mathrm{w}\right)$, where long-term studies of blue tits and pied flycatchers are ongoing. Blue tits and pied flycatchers are small, hole-nesting, insectivorous passerines that readily breed in artificial nest-boxes. Blue tits are residents, while pied flycatchers are long-distance migrants wintering in West Africa. In the study localities, they differ in breeding phenology (blue tits start breeding in the second half of April, pied flycatchers in the second week of May), brood size (7-12 for blue tits, 4-8 for pied flycatchers), and body mass (10 g for blue tits, $12 \mathrm{~g}$ for pied flycatchers). Nest composition differs strikingly between pied flycatchers in Lozoya and those in Valsaín. Pied flycatchers in Valsaín incorporate strips of bark of Cistus laurifolius, which is the main component of the shrub layer there but does not grow in the Lozoya locality. In Lozoya, Cistus bark is replaced by oak and pine bark (there are scattered pines [Pinus sylvestris] in both study localities) and greater amounts of dry grass. Given that bark of certain species may have insecticidal properties, we aimed to test if different types of pied flycatcher nests led to different ectoparasite faunas. 
The mites infesting pied flycatcher and blue tit nests in our study localities belong to the species Dermanyssus gallinoides (Acari: Dermanyssidae), in which both adult and some nymphal stages are haematophagous. This mite has short generation times and can readily build up very large populations. Mites have been shown to have detrimental effects on pied flycatcher reproductive success in central Spain (Merino \& Potti, 1995; 1996; Moreno et al., 2008a). Blowfly larvae of the dipteran Protocalliphora azurea (Diptera: Calliphoridae) are found in pied flycatcher and blue tit nests in our study localities. Fleas considered in this study belong to the species Ceratophyllus gallinae. For a brief description of life cycle characteristics of these parasites see Merino and Potti (1995; 1996). None of these nest-dwelling ectoparasites shows a high degree of host specificity (George, 1959; Moss, 1978; González-Mora \& Peris, 1988; Tripet \& Richner, 1997; Puchala, 2004; Mazgajski, 2007).

\section{DIFFERENCES IN NEST COMPOSITION}

In 2006 and 2007, all pied flycatcher nests in Valsaín were collected after the end of breeding in clean, sealed plastic bags and subsequently subjected to arthropod extraction (see below) and disassembled to estimate composition. Nests of blue tits not included in any experiment in Valsaín were also collected in those years. In Lozoya in 2006, a nest removal experiment was conducted in which certain nests were removed to induce pied flycatchers and blue tits to build a second nest (see Moreno et al., 2008b for pied flycatchers). These removed nests were used in nest exchange experiments in 2007 in Valsaín (see below). Pied flycatcher and blue tit control nests in the nest removal experiments in Lozoya in 2006 were collected after the end of breeding and treated in the same way as Valsaín nests. Pied flycatcher nests in Lozoya in 2007 were also collected for studying nest composition.

After arthropod removal, nests were separated into different components. Components of each nest were separately weighed on electronic balances with $0.1 \mathrm{~g}$ precision. Nest composition was expressed in proportions of mass of the following materials: Cistus bark, dry grass, moss, dry oak leaves, dry oak flowers, pine bark, oak bark, feathers, and hair.

\section{DIFFERENCES IN ECTOPARASITE PRESENCE}

All nests used for nest composition studies except those of Lozoya in 2007 were previously processed for estimating ectoparasite abundance. Counts were necessary in order to establish a distribution of abundances that could be used to derive relative indices of infestation intensity for statistical analyses. Soon after nestlings fledged (days 17-18 for flycatchers, days 19-20 for blue tits), all nests were removed in sealed plastic bags and taken to the laboratory, where they were subjected to arthropod removal in Berlese funnels for $48 \mathrm{~h}$ until nests were thoroughly dried and no arthropods were moving in the nest material. Funnels were equipped with 60-W light bulbs, and nest associates were driven into jars attached to the bottom of the funnels containing about $150 \mathrm{~mL}$ of a $70 \%$ ethanol solution. The content of the jars was examined by taking samples, which were spread on a Petri dish of $90 \mathrm{~mm}$ diameter to get a homogeneous distribution of the parasites collected. The Petri dish had a squared paper (area $=36 \mathrm{~cm}^{2}$ ) at the bottom divided into 9 subsquares. Three of the 9 subsquares inside the square and 2 of the 4 areas inside the Petri dish surrounding the square were searched for ectoparasites with the aid of a stereoscopic microscope (Olympus SZX7). The number of parasites in the dish was calculated as the number counted in the 3 squares multiplied by 3 plus twice the number counted in the 2 areas external to the squares. The Petri dish was then cleaned and the process was repeated until the entire content of the jar had been processed. The separate counts were then summed to obtain an estimate of the total number of mites and fleas in the jar. This method provides an accurate estimate of parasitic mites infesting nests, as shown in Merino (1993). Although flea counts from Berlese funnels do not adequately estimate flea abundance (Harper, Marchant \& Boddington, 1992), we analyzed flea presence/absence (see below), for which these counts may give a true picture (Merino \& Potti, 1996). Blowfly puparia in the nest material were also counted (Merino \& Potti, 1996).

\section{NEST EXCHANGE EXPERIMENT IN 2007}

In Lozoya in 2006, certain unused completed blue tit and pied flycatcher nests were collected in hermetically closed plastic boxes of the same dimensions as nests to preserve their structure intact. These unused nests were extracted in the context of an experiment forcing females to build 2 nests (see Moreno et al., 2008b for pied flycatchers) and stored in a freezer at $-20{ }^{\circ} \mathrm{C}$ to be used in nest exchanges in Valsaín in the next breeding season.

In 2007 in Valsaín, nest-boxes were checked daily to detect the first indications of nest construction by pied flycatchers, and the process of nest construction was followed through daily visits until the first egg appeared, when the nest was extracted from the nest-box and replaced by a different unused completed nest in which the egg was placed. Nests are sufficiently compact to allow removal, transport, and introduction in the nest-box without deterioration. Three nest exchange treatments were randomly allocated to pied flycatcher nest-boxes in a certain sequence, guaranteeing approximately equal sample sizes: 1) simultaneously completed pied flycatcher nests from the study locality (manipulation control treatment); 2) completed pied flycatcher nests from Lozoya that were removed in 2006 and stored in a freezer until manipulation (locality treatment); and 3) completed blue tit nests from Lozoya (see below) that were removed in 2006 and stored in a freezer until manipulation (species treatment). Thus, none of the pairs in these treatments bred in their own nests. All experimentally introduced nests were treated in a microwave oven for 1 minute before being placed in the new nest-box. This treatment ensured that experimental nests did not contain live arthropods when placed in the nest-box (Rendell \& Verbeek, 1996). A fourth group of nests was kept as a pure control group (no microwave treatment, no exchange). Freezer storage guaranteed that experimental nests remained fresh independently of year of construction (2007 for treatment 1, 2006 for treatments 2 and 3). Finally, blue tit nests were followed in the same way as pied flycatcher nests and considered 
as blue tit controls to compare with treatment 3. Six blue tit nests that were taken over by pied flycatchers soon after completion were considered as a group of flycatcher nests constructed by blue tits in Valsaín in 2007 (to compare with pied flycatcher nests constructed by blue tits in Lozoya in 2006, treatment 3 above). Twenty nest-boxes were assigned to each of experimental treatments $1-3$, but parental desertions led to reductions in sample sizes.

In 2007 in Valsaín, pied flycatcher nestlings were ringed, weighed, and measured as to tarsus length with a digital calliper ( $0.01 \mathrm{~mm}$ precision) on day 12 (hatching day = day 0 ). Nests were collected for ectoparasite removal and nest composition studies after young fledged (see above).

\section{STATISTICAL ANALYSES}

As the distributions of proportions of different nest materials could not be normalized through any transformation, non-parametric tests were used to compare species, localities, and years. Given the number of tests performed on nest composition data, only $P$ values lower than 0.005 are considered significant $(0.05$ divided by number of nest components tested or Bonferroni correction). Given the total lack of normality in the ectoparasite abundance data and the incapacity of any transformation to normalize the data, their numbers were converted into binomial variables and analyzed with logistic regression models. To this end, numbers were scored as many or few, with the median as limit. Given the high frequency of complete absences, the median was very low in most cases ( 0 for fleas, 9 for blowflies, and 14 for mites in Valsaín in 2006, 0 for fleas and 7 for blowflies and mites in Valsaín in 2007, and 0 for fleas and blowflies and 6 for mites in Lozoya in 2006). The score represents pure prevalence for fleas and close to it for mites, whose number may reach into the hundreds or thousands in a nest (Merino \& Potti, 1995).

Frequencies of scores above and below the median (see above) were analyzed with $\mathrm{X}^{2}$ analyses of frequencies. To correct for brood size and breeding phenology, 2 variables that may correlate with ectoparasite abundance, we performed logistic analyses on binomial distributions for all ectoparasites. For the pied flycatcher nest exchange experiment, we used constructing species (blue tit, pied flycatcher) and locality of provenance (Valsaín, Lozoya) as main effects together with their interaction. In order to avoid differences in parental quality between treatments, extremely late nests were excluded from analyses of the results of the experiment. These nests correspond to broods hatching 1 SD after the mean hatching date in the 2007 population of pied flycatchers in Valsaín; all were from pure control nests. Eighteen manipulated (treatment 1) and 27 control (treatment 4) nests built by flycatchers in Valsaín, 15 manipulated (treatment 2) nests built by flycatchers in Lozoya, 17 nests (treatment 3) built by blue tits in Lozoya, and 6 nests built by blue tits in Valsaín that were evicted by flycatchers after nest completion were analyzed. To check the effect of nesting species on ectoparasite abundances, we tested the 6 blue tit nests containing pied flycatcher nestlings against 32 nests containing blue tit nestlings that had also been built by blue tits in Valsaín. These 6 nests were also compared with the 17 nests built by blue tits in Lozoya but experimentally intro- duced into flycatcher nest-boxes, in order to check if nests collected in 2006 differed from those built in 2007.

\section{Results}

VARIATION IN NEST COMPOSITION AND ECTOPARASITES AMONG CONTROL NESTS OF BOTH SPECIES

\section{NEST COMPOSITION AND HOST SPECIES}

Blue tits constructed nests mainly out of moss and hair in both study localities, while pied flycatchers used mainly Cistus bark, dry grass, and oak leaves in Valsaín and dry grass, oak leaves, and pine and oak bark in Lozoya to build nests (Tables I, II). There is a highly significant interspecific difference in nest composition in both study localities (Table I). Nest dry mass differed only between species in Valsaín in 2007, pied flycatchers building heavier nests including dry oak flowers in that year only (Table I).

\section{LOCAL AND TEMPORAL VARIATION IN NEST COMPOSITION}

Flycatchers in Valsaín built significantly heavier nests than those in Lozoya in both years, mainly due to the intense use of Cistus bark for nest construction in Valsaín (Table II). Flycatchers in Lozoya used much more dry grass, differences in other components showing yearly variation (Table II). Blue tits built very similar nests in both study localities (Table II), so blue tit nests could be exchanged between localities.

Pied flycatchers in Valsaín built heavier nests in 2007 than in 2006 (Mann-Whitney test, $Z=2.77, P=0.006$ ), mainly due to the use of dry oak flowers in the year when oaks in the study locality flowered $(Z=5.14, P<0.001)$. Pied flycatchers in Lozoya did not change composition or nest size between years (all $P>0.09$ ). For blue tits in Valsaín there were no differences in nest composition or size between years (all $P>0.08$ ). Thus, blue tit nests from 2006 could be used in nest exchange experiments in 2007 (see below).

\section{ECTOPARASITES AND HOST SPECIES}

In 2006 in Valsaín, the prevalences of fleas and blowflies were significantly higher in blue tit nests (Table III). In 2007 in Valsaín, the prevalences of blowflies were significantly higher in blue tit nests (Table III). In 2006 in Lozoya, the prevalence of fleas was significantly higher in blue tit nests, while the prevalence of mites was significantly higher in pied flycatcher nests (Table III). The prevalences of blowflies and mites in blue tit nests were higher in Valsaín than in Lozoya in $2006\left(X^{2}=4.93, P=0.0264\right.$ and $X^{2}=7.1, P=0.008$, respectively), while there were no differences for pied flycatcher nests $\left(X^{2}=1.82, P=0.178\right.$ and $X^{2}=0.93, P=0.33$, respectively). On the other hand, the prevalences of fleas in 2006 in both blue tit and pied flycatcher nests were higher in Lozoya than in Valsaín $\left(X^{2}=12.6, P<0.001\right.$ and $X^{2}=7.81, P<0.01$, respectively) Thus, blue tits suffered more from fleas and blowflies than pied flycatchers but seemed to suffer less from mites in one localities, although there was both local and temporal variation in effects.

Some interspecific differences may be due to differences in breeding phenology (blue tits breed earlier) and brood size (blue tits have larger broods). Therefore, we 
TABLE I. Proportional (mean \pm SE) composition and total mass of blue tit and pied flycatcher control nests in Valsaín 2006-2007 and Lozoya 2006, and Mann-Whitney U-test comparisons.

\begin{tabular}{|c|c|c|c|c|}
\hline & Blue tit & Pied flycatcher & $Z$ & $P$ \\
\hline VALSAÍN 2006 & $n=17$ & $n=71$ & & \\
\hline Cistus bark & $0.05 \pm 0.05$ & $0.62 \pm 0.02$ & 6.13 & $<0.001$ \\
\hline Dry grass & $0.06 \pm 0.04$ & $0.22 \pm 0.02$ & 3.82 & $<0.001$ \\
\hline Oak leaves & $0.00 \pm 0.02$ & $0.13 \pm 0.01$ & 6.06 & $<0.001$ \\
\hline Pine bark & $0.00 \pm 0.01$ & $0.03 \pm 0.01$ & 2.82 & 0.005 \\
\hline Oak bark & $0.00 \pm 0.01$ & $0.00 \pm 0.00$ & 1.08 & 0.278 \\
\hline Moss & $0.63 \pm 0.02$ & $0.00 \pm 0.00$ & 7.72 & $<0.001$ \\
\hline Hair & $0.23 \pm 0.02$ & $0.00 \pm 0.01$ & 7.69 & $<0.001$ \\
\hline Feathers & $0.02 \pm 0.00$ & $0.00 \pm 0.00$ & 4.68 & $<0.001$ \\
\hline Total mass (g) & $38.1 \pm 10.7$ & $28.9 \pm 0.70$ & 1.31 & 0.188 \\
\hline VALSAÍN 2007 & $n=32$ & $n=39$ & & \\
\hline Cistus bark & $0.07 \pm 0.03$ & $0.63 \pm 0.03$ & 6.94 & $<0.001$ \\
\hline Dry grass & $0.08 \pm 0.02$ & $0.16 \pm 0.02$ & 2.90 & 0.004 \\
\hline Oak leaves & $0.01 \pm 0.02$ & $0.10 \pm 0.01$ & 6.52 & $<0.001$ \\
\hline Pine bark & $0.01 \pm 0.02$ & $0.07 \pm 0.02$ & 3.44 & $<0.001$ \\
\hline Oak flowers & $0.00 \pm 0.01$ & $0.03 \pm 0.01$ & 3.13 & 0.002 \\
\hline Moss & $0.60 \pm 0.02$ & $0.00 \pm 0.02$ & 7.76 & $<0.001$ \\
\hline Hair & $0.21 \pm 0.02$ & $0.00 \pm 0.02$ & 6.42 & $<0.001$ \\
\hline Feathers & $0.01 \pm 0.00$ & $0.00 \pm 0.00$ & 2.84 & 0.004 \\
\hline Total mass (g) & $22.6 \pm 1.80$ & $34.5 \pm 1.60$ & 4.59 & $<0.001$ \\
\hline LOZOYA 2006 & $n=9$ & $n=24$ & & \\
\hline Cistus bark & $0.00 \pm 0.01$ & $0.01 \pm 0.00$ & 1.09 & 0.274 \\
\hline Dry grass & $0.07 \pm 0.06$ & $0.59 \pm 0.03$ & 4.37 & $<0.001$ \\
\hline Oak leaves & $0.00 \pm 0.03$ & $0.12 \pm 0.02$ & 3.91 & $<0.001$ \\
\hline Pine bark & $0.00 \pm 0.05$ & $0.15 \pm 0.03$ & 3.20 & 0.001 \\
\hline Oak bark & $0.00 \pm 0.04$ & $0.12 \pm 0.03$ & 2.75 & 0.006 \\
\hline Oak flowers & $0.02 \pm 0.01$ & $0.00 \pm 0.01$ & 1.63 & 0.102 \\
\hline Moss & $0.60 \pm 0.02$ & $0.01 \pm 0.01$ & 5.20 & $<0.001$ \\
\hline Hair & $0.28 \pm 0.03$ & $0.01 \pm 0.02$ & 5.01 & $<0.001$ \\
\hline Feathers & $0.02 \pm 0.01$ & $0.00 \pm 0.00$ & 5.01 & 0.019 \\
\hline Total mass (g) & $24.5 \pm 14.6$ & $21.8 \pm 1.20$ & 0.85 & 0.396 \\
\hline
\end{tabular}

TABLE II. Proportional (mean \pm SE) composition and total mass of pied flycatcher and blue tit control nests in the 2 study localities and 2 y and Mann-Whitney $U$-test comparisons between localities.

\begin{tabular}{|c|c|c|c|c|}
\hline & Valsaín & Lozoya & $Z$ & $P$ \\
\hline PIED FLYCATCHER 2006 & $n=71$ & $n=24$ & & \\
\hline Cistus bark & $0.62 \pm 0.02$ & $0.01 \pm 0.01$ & 7.30 & $<0.001$ \\
\hline Dry grass & $0.22 \pm 0.02$ & $0.59 \pm 0.03$ & 6.07 & $<0.001$ \\
\hline Oak leaves & $0.13 \pm 0.01$ & $0.12 \pm 0.02$ & 0.46 & 0.644 \\
\hline Pine bark & $0.03 \pm 0.01$ & $0.15 \pm 0.03$ & 4.00 & $<0.001$ \\
\hline Oak bark & $0.00 \pm 0.00$ & $0.12 \pm 0.03$ & 7.18 & $<0.001$ \\
\hline Moss & $0.00 \pm 0.00$ & $0.01 \pm 0.01$ & 0.77 & 0.439 \\
\hline Hair & $0.00 \pm 0.01$ & $0.01 \pm 0.02$ & 0.51 & 0.611 \\
\hline Total mass (g) & $28.9 \pm 0.70$ & $21.8 \pm 1.20$ & 4.54 & $<0.001$ \\
\hline PIED FLYCATCHER 2007 & $n=39$ & $n=33$ & & \\
\hline Cistus bark & $0.63 \pm 0.03$ & $0.04 \pm 0.03$ & 7.26 & $<0.001$ \\
\hline Dry grass & $0.16 \pm 0.03$ & $0.52 \pm 0.03$ & 6.18 & $<0.001$ \\
\hline Oak leaves & $0.10 \pm 0.03$ & $0.24 \pm 0.03$ & 2.67 & 0.008 \\
\hline Pine bark & $0.07 \pm 0.02$ & $0.13 \pm 0.03$ & 1.78 & 0.075 \\
\hline Oak flowers & $0.03 \pm 0.01$ & $0.00 \pm 0.01$ & 3.61 & $<0.001$ \\
\hline Moss & $0.00 \pm 0.00$ & $0.01 \pm 0.00$ & 0.70 & 0.481 \\
\hline Feathers & $0.00 \pm 0.00$ & $0.00 \pm 0.00$ & 0.92 & 0.358 \\
\hline Total mass (g) & $34.5 \pm 1.50$ & $19.4 \pm 1.40$ & 6.04 & $<0.001$ \\
\hline BLUE TIT 2006 & $n=17$ & $n=9$ & & \\
\hline Cistus bark & $0.05 \pm 0.05$ & $0.00 \pm 0.01$ & 1.97 & 0.048 \\
\hline Dry grass & $0.06 \pm 0.04$ & $0.07 \pm 0.06$ & 0.44 & 0.657 \\
\hline Pine bark & $0.00 \pm 0.01$ & $0.00 \pm 0.05$ & 1.37 & 0.169 \\
\hline Oak bark & $0.00 \pm 0.01$ & $0.00 \pm 0.04$ & 0.52 & 0.600 \\
\hline Oak flowers & $0.00 \pm 0.01$ & $0.02 \pm 0.01$ & 1.37 & 0.169 \\
\hline Moss & $0.63 \pm 0.02$ & $0.60 \pm 0.02$ & 0.38 & 0.706 \\
\hline Hair & $0.23 \pm 0.02$ & $0.28 \pm 0.03$ & 0.57 & 0.571 \\
\hline Feathers & $0.02 \pm 0.00$ & $0.02 \pm 0.01$ & 0.24 & 0.809 \\
\hline Total mass (g) & $38.1 \pm 10.7$ & $24.5 \pm 14.6$ & 0.62 & 0.535 \\
\hline
\end{tabular}


conducted logistic regression analyses for the 3 ectoparasites on nests of each host species separately, with brood size at fledging and hatching date as explanatory variables. This was done for Valsaín in 2006 and 2007. In both cases, samples of control nests were adequate (60 blue tit and 76 flycatcher nests in 2006, 57 blue tit and 36 flycatcher nests in 2007). Neither brood size nor hatching date showed any significant effect for any ectoparasite for either host species in 2007 (all $P>0.07$ for blue tits, all $P>0.11$ for flycatchers) or for flycatchers in 2006 ( $P>0.16$ in all cases). However, there was evidence that brood size negatively affected the presence of mites (Estimate $=-0.41 \pm 0.19$, Wald $=4.73$, $P=0.030$ ) and positively affected the presence of blowflies (Estimate $=0.31 \pm 0.16$, Wald $=1.49, P=0.043$ ) for blue tits in 2006. Thus, the possibility that blue tits may suffer more from blowflies and less from mites than flycatchers due to their larger broods cannot be rejected.

\section{LOCAL AND TEMPORAL VARIATION IN ECTOPARASITE PREVALENCE}

In 2006, pied flycatchers showed significantly higher prevalences of blowflies and fleas in Lozoya than in Valsaín when controlling for hatching date and brood size (Estimate $=0.51 \pm 0.24$, Wald $=4.31, P=0.038$ and Estimate $=-0.74 \pm 0.27$, Wald $=7.75, P=0.005$, respectively), while blue tits showed a higher prevalence of mites in Valsaín than in Lozoya (Estimate $=1.08 \pm 0.55$, Wald $=3.82$, $P=0.050)$ and a higher prevalence of fleas in Lozoya than in Valsaín (Estimate $=1.18 \pm 0.40$, Wald $=8.60, P=0.003$ ). Other differences were far from significance. Thus, the population of flycatchers preferentially using Cistus bark showed lower ectoparasite scores in $1 \mathrm{y}$.

There were no interannual differences in prevalences for blue tits in Valsaín (all $P$ in logistic analyses $>0.17$ ). Flycatchers in Valsaín had a significantly higher prevalence of fleas in 2007 than in 2006 (Estimate $=0.74 \pm 0.27$, Wald $=7.75, P=0.005)$. Thus, local variation seems to be more important for blue tits, while flycatchers experience both local and temporal variation in infestation. Fleas appear to be the most variable parasite species with respect to prevalence.

\section{EXPERIMENTAL MANIPULATION OF NESTS}

\section{ECTOPARASITES AND NEST STORAGE AND HANDLING}

The effect of nest storage and handling was estimated by comparing 17 nests constructed by blue tits in 2006 in Lozoya and introduced in flycatcher nest-boxes in 2007 in Valsaín with 6 nests constructed by blue tits in Valsaín in 2007 and occupied by flycatchers soon after nest completion, a natural experiment without manipulation. No effect of handling for any ectoparasite species was detected when correcting for brood size and hatching date $(P>0.23$ in all cases). We also checked if ectoparasite numbers were affected by the microwave treatment by comparing nests constructed by flycatchers in Valsaín and occupied by flycatchers in Valsaín in 2007 according to whether they had been subjected to the microwave treatment or not (manipulated controls against pure controls) and controlling for brood size and phenology. No ectoparasite species was affected by the manipulation $(P>0.13)$. Accordingly, we can conclude that collection in a different year and processing in the microwave oven apparently did not affect subsequent ectoparasite infestation. Thus, in our analyses we pooled nests from treatments 1 and 4, and included also the 6 blue tit nests from Valsaín occupied by pied flycatchers.

\section{NEST EXCHANGE EXPERIMENT AND ECTOPARASITES}

We compared ectoparasite scores in nests with pied flycatcher nestlings made by flycatchers and blue tits by introducing the constructing species (blue tit, flycatcher) and the locality where nests were built (Valsaín, Lozoya) as independent factors together with their interaction. To that end, the 6 blue tit nests taken over by pied flycatchers were included in the analyses (see above). Hatching date and brood size were introduced as covariates in all analyses. Neither constructing species nor locality of provenance nor their interaction explained ectoparasite infestation in pied flycatcher nests for any parasite species except in the case of locality for fleas (Table IV). Flea presence was more frequent in nests constructed in Valsaín than in those from Lozoya, and there was no interaction of locality with constructing species (Figure 1).

TABLE III. Prevalences of different ectoparasites in blue tit and pied flycatcher control nests and $\mathrm{X}^{2}$ tests of frequencies (number of nests are in parentheses).

\begin{tabular}{lcccr}
\hline \hline & Blue tit & Pied flycatcher & $X^{2}$ & $P$ \\
\hline VALSAín 2006 & & & & \\
Mites & $55.7(61)$ & $50.0(78)$ & 0.45 & 0.501 \\
Fleas & $37.7(61)$ & $14.7(78)$ & 11.7 & $<0.001$ \\
Blowflies & $77.0(61)$ & $32.9(76)$ & 26.5 & $<0.001$ \\
VALSAÍn 2007 & & & & \\
Mites & $69.0(29)$ & $84.6(39)$ & 2.37 & 0.124 \\
Fleas & $55.2(29)$ & $46.1(39)$ & 0.54 & 0.462 \\
Blowflies & $100(31)$ & $55.0(40)$ & 18.7 & $<0.001$ \\
LozoYA 2006 & & & & \\
Mites & $22.7(22)$ & $59.1(44)$ & 7.79 & 0.005 \\
Fleas & $81.8(22)$ & $34.1(44)$ & 13.4 & $<0.001$ \\
Blowflies & $60.0(15)$ & $45.9(37)$ & 0.84 & 0.358 \\
\hline
\end{tabular}

TABLE IV. Results of logistic regression analyses for presence/absence of mites, fleas, and blowflies in nests occupied by pied flycatchers in Valsaín in 2007 in relation to hatching date, brood size, nest-building species (blue tit, pied flycatcher), locality (Valsaín, Lozoya), and their interaction, in the context of a nest exchange experiment.

\begin{tabular}{lrrrc}
\hline \hline & Estimate & SE & Wald Stat. & $P$ \\
\hline Mites & & & & \\
Hatching date & 0.06 & 0.04 & 2.13 & 0.144 \\
Brood size & 0.05 & 0.25 & 0.05 & 0.830 \\
Nest building sp. & -0.38 & 0.35 & 1.18 & 0.278 \\
Locality & 0.20 & 0.37 & 0.31 & 0.581 \\
Interaction Sp. $\times$ L & 0.12 & 0.36 & 0.11 & 0.743 \\
FLEAS & & & & \\
Hatching date & -0.02 & 0.05 & 0.14 & 0.706 \\
Brood size & 0.03 & 0.27 & 0.01 & 0.910 \\
Nest building sp. & 0.40 & 0.42 & 0.93 & 0.334 \\
Locality & 0.95 & 0.44 & 4.63 & 0.031 \\
Interaction Sp. $\times$ L & -0.05 & 0.43 & 0.18 & 0.903 \\
BLowFLIES & & & & \\
Hatching date & 0.13 & 0.05 & 6.57 & 0.010 \\
Brood size & 0.85 & 0.35 & 5.86 & 0.015 \\
Nest building sp. & -4.24 & 667 & $<0.001$ & 0.995 \\
Locality & -4.59 & 667 & $<0.001$ & 0.994 \\
Interaction Sp. $\times$ L & -4.19 & 667 & $<0.001$ & 0.995 \\
\hline
\end{tabular}




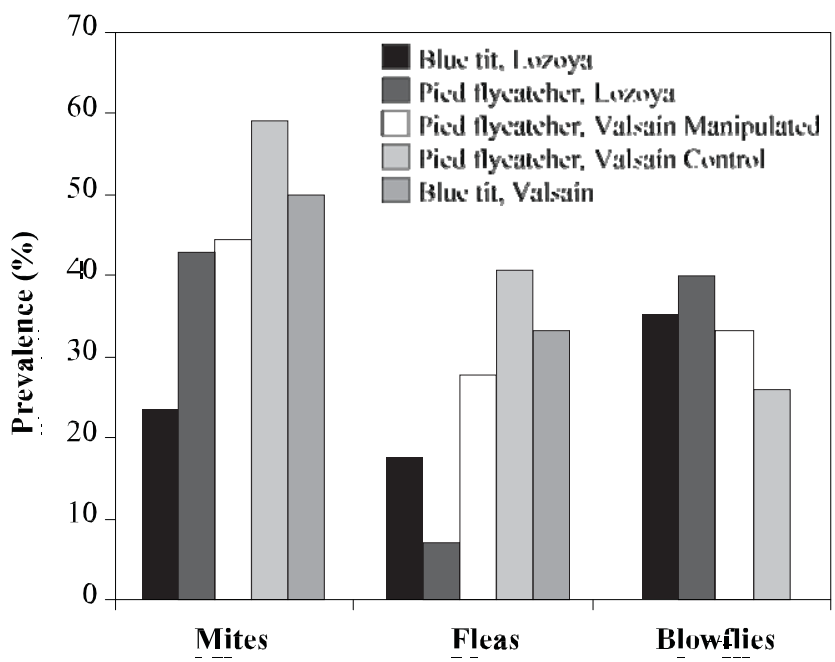

Figure 1. Prevalences (\% of presence scores) of mites, blowflies, and fleas in pied flycatcher nests of Valsaín in 2007 according to experimental treatment (nest-constructing species and locality of construction). Prevalence of blowflies in the small sample of blue tit nests taken over by

Another way to test the hypothesis of nest composition affecting ectoparasites is to compare nests built by the same species but occupied by different host species. We compared ectoparasite abundances in nests built by blue tits but occupied by either blue tits or pied flycatchers. The proportions of nests infested by blowflies $(0.82, n=60)$ and mites $(0.55$, $n=58$ ) were higher for blue tits than for pied flycatchers $\left(0.30, n=23\right.$ in both cases) $\left(X^{2}=17.6, P<0.001\right.$ and $X^{2}=4.0, P=0.044$, respectively), while the difference for fleas was not quite significant $(0.45$ for blue tits versus 0.22 for pied flycatchers; $\left.X^{2}=3.7, P=0.054\right)$. The difference for mites was in the direction opposite to that found in some earlier analyses, indicating that differences in mite infestation according to host species are less consistent than for the other 2 parasite species. We cannot reject the possibility that the difference for blowflies was due to the larger broods of blue tits (see above).

\section{NEST EXCHANGE EXPERIMENT AND HOST REPRODUCTIVE SUCCESS}

When analyzing the effects of type of nest and ectoparasites on mean nestling measurements in pied flycatcher broods included in the nest manipulation experiment (see above), only mites showed a negative effect on mean nestling mass when controlling for hatching date, brood size, and nest-constructing species (Table V). Mean tarsus length was not affected by any ectoparasite in that year (Table V). Type of nest did not show any significant effect (Table V).

Reproductive success in pied flycatcher nests included in the experiment (number of fledged young divided by brood size) was not affected by type of nest, presence of mites or fleas, or the interaction of nest type with ectoparasite presence when controlling for hatching date (all $P>0.30$ ). Only blowflies showed a positive association with reproductive success $\left(F_{1,68}=5.9, P=0.018\right)$ when controlling for hatching date, nest type, and the interaction of nest type and blowfly presence. This is presumably due to the positive association of blowfly presence with brood size (see above).
TABLE V. Results of GLM analyses for effects of ectoparasite presence and nest-constructing species on mean nestling measurements in pied flycatcher broods in Valsaín in 2007, controlling for hatching date and brood size.

\begin{tabular}{|c|c|c|c|c|}
\hline & Parameter & SE & $F$ & $P$ \\
\hline \multicolumn{5}{|l|}{ TARSUS LENGTH } \\
\hline Hatching date & -0.05 & 0.01 & 21.10 & $<0.001$ \\
\hline Brood size & 0.13 & 0.14 & 0.23 & 0.633 \\
\hline Nest type & 1.00 & 0.46 & 0.53 & 0.469 \\
\hline Mites & -0.05 & 0.07 & 1.44 & 0.234 \\
\hline Nest type $\times$ Mites & -0.08 & 0.07 & 1.45 & 0.233 \\
\hline Hatching date & -0.05 & 0.01 & 28.20 & $<0.001$ \\
\hline Brood size & 0.03 & 0.05 & 0.27 & 0.602 \\
\hline Nest type & 0.04 & 0.07 & 0.27 & 0.602 \\
\hline Fleas & 0.11 & 0.07 & 2.69 & 0.105 \\
\hline Nest type $\times$ Fleas & 0.09 & 0.07 & 1.78 & 0.186 \\
\hline Hatching date & -0.05 & 0.01 & 23.20 & $<0.001$ \\
\hline Brood size & 0.02 & 0.06 & 0.07 & 0.792 \\
\hline Nest type & 0.01 & 0.07 & 0.01 & 0.942 \\
\hline Blowflies & 0.01 & 0.07 & 0.01 & 0.932 \\
\hline Nest type $\times$ Blowflies & 0.01 & 0.07 & 0.01 & 0.907 \\
\hline \multicolumn{5}{|l|}{ Mass } \\
\hline Hatching date & -0.08 & 0.02 & 19.10 & $<0.001$ \\
\hline Brood size & -0.16 & 0.10 & 1.66 & 0.202 \\
\hline Nest type & -0.23 & 0.12 & 0.06 & 0.806 \\
\hline Mites & -0.55 & 0.12 & 4.10 & 0.047 \\
\hline Nest type $\times$ Mites & -0.37 & 0.12 & 0.54 & 0.463 \\
\hline Hatching date & -0.11 & 0.02 & 25.70 & $<0.001$ \\
\hline Brood size & -0.16 & 0.11 & 1.56 & 0.216 \\
\hline Nest type & 0.11 & 0.14 & 2.03 & 0.158 \\
\hline Fleas & 0.21 & 0.14 & 0.59 & 0.443 \\
\hline Nest type $\times$ Fleas & 0.29 & 0.14 & 1.61 & 0.208 \\
\hline Hatching date & -0.12 & 0.02 & 24.00 & $<0.001$ \\
\hline Brood size & -0.24 & 0.13 & 2.01 & 0.160 \\
\hline Nest type & -0.03 & 0.15 & 0.37 & 0.544 \\
\hline Blowflies & 0.20 & 0.15 & 0.14 & 0.706 \\
\hline Nest type $\times$ Blowflies & -0.06 & 0.15 & 1.26 & 0.264 \\
\hline
\end{tabular}

\section{Discussion}

We confirmed our initial assumptions that (1) nest composition differs between sympatric species breeding in the same nest environment (nest-boxes), (2) that nest composition differs between populations of the same species depending on availability of preferred plants, (3) that infestation by different ectoparasite species differs between sympatric species breeding in common macro and microenvironments, and (4) that presence of different ectoparasites differs for the same species according to breeding locality, with lower incidence in the locality where preference for a certain nest material is expressed. This justifies our experimental test of the possibility that interspecific and intraspecific differences in ectoparasite abundances depend on nest composition. This possibility was not confirmed experimentally, however, and neither was it shown that nest composition has an effect on reproductive success. Although the experimental results were only confirmed for pied flycatchers, their clarity suggests that nest composition is not the explanation for differences in ectoparasite prevalences. These results confirm those obtained by Remes and 
Krist (2005) for differences in blowfly infestation between great tits and collared flycatchers in central Europe but widen the analysis to cover two different but related host species and their whole nest-dwelling ectoparasite faunas.

\section{INTERSPECIFIC DIFFERENCES IN NEST COMPOSITION}

Nest structure and composition in birds is highly variable at both the interspecific and intraspecific levels (Collias \& Collias, 1984). However, it has been suggested that availability of nest materials may act as a constraint on nest site selection and even on breeding range (Hansell, 2000). Of 20 species of Ficedula flycatchers for which there is information about nest composition and structure (del Hoyo, Elliott \& Christie, 2006), 11 are hole nesters. Of these, 6 have nest-cups whose composition includes moss as the first term in the description of components (del Hoyo, Elliott \& Christie, 2006). Of 9 non-hole nesters, 4 include moss as one of the main components. Thus, nest-site selection and nest composition show high variability within the genus Ficedula, and moss appears to be a common main constituent of Ficedula flycatcher nests. This is not the case for the family Paridae, including the genus Cyanistes, as of 49 species whose nest has been described, all except 2 species in Asia and the Canary Island blue tit do build nests mainly of green moss (del Hoyo, Elliott \& Christie, 2007). No phylogenetic constraint appears to be operating to maintain a clear difference between our study species with respect to nest composition, as moss is a common constituent of Ficedula nests generally. However, European Ficedula flycatchers that do not use moss for nest building are the only species wintering in African dry woodlands and savannahs (the other species are resident or winter in south or southeast Asia). The geographic origin of these species may thus explain their rejection of the moss abundantly available in European forests.

\section{INTRASPECIFIC DIFFERENCES IN NEST COMPOSITION}

The large local intraspecific variation in nest composition shown here for pied flycatchers is in accordance with the flexibility in nest material selection shown interspecifically in the genus Ficedula. Dry grass, leaves, and bark are abundantly available in both study localities but are to a high degree substituted by Cistus bark where this material is available, leading to considerably heavier and bulkier nests. The causes for this clear preference for Cistus bark are unknown, but they could be due to some association with nest-dwelling ectoparasites. In fact, in the locality where the preference is expressed, Valsaín, ectoparasites show a lower incidence. We show here experimentally that this is not the reason for the preference. The structural qualities of Cistus bark, which easily turns itself into rings, may alternatively explain the preference. The local variation in ectoparasite infestation could be due to local climatic variation (Merino \& Potti, 1996). On the other hand, the absence of local variation in blue tit nest composition shown here suggests that tits may be more phylogenetically conservative with respect to nest building. Alternatively, it may simply reflect the reality that moss is abundantly available in most blue tit habitats. The fact that Canary Island blue tits do not use moss for nest construction due to its scarcity there (del Hoyo,
Elliott \& Christie, 2007) suggests that the second alternative is probably more correct.

The effect of locality of origin of nests on flea prevalence detected in our experiment could be attributed to nest storage and manipulation, as all nests from Lozoya had been collected in 2006, frozen, and processed in a microwave oven prior to introduction in nest-boxes in Valsaín in 2007. Flea presence was not affected by treatment when comparing only nests built by blue tits, nor was the microwave treatment relevant for explaining differences in flea presence in nests built by pied flycatchers from Valsaín. However, fleas do appear to be more sensitive to changes in ambient conditions than mites and blowflies, as they showed more local and temporal variation in prevalence (see also Merino \& Potti, 1996). Thus, the effect of locality may be due to an artefact of nest manipulation and storage affecting attractiveness for fleas. However, controlling for this unwanted effect, nest building species still had no detectable effect on flea prevalence, nor any interaction with locality.

\section{INTERSPECIFIC DIFFERENCES IN ECTOPARASITE ABUNDANCE}

Known differences in ectoparasite abundance between nests of pied flycatchers and tits concern mainly comparisons with the great tit, a close relative of the blue tit. Thus, Bauchau (1998) showed that great tits presented higher prevalences of fleas in 2 study localities and of mites in 1 of 2 study localities in the Netherlands. Harper, Marchant, and Boddington (1992) showed the same for fleas in Britain, while Eeva, Lehikoinen, and Nurmi (1994) obtained higher prevalences in great tit nests for blowflies and fleas in Finland. Remes and Krist (2005) compared great tits with collared flycatchers, a close relative of the pied flycatcher, and found again a higher prevalence of blowflies in tit nests. We here confirm that blue tits have higher prevalences of fleas and blowflies in at least some years and study localities in central Spain, while pied flycatchers show a higher prevalence of mites in at least 1 study locality. Thus, our results contradict the finding that tits in general also show higher prevalences of mites than pied flycatchers (Bauchau, 1998). Tits raise larger broods than flycatchers, and both mites and blowflies show associations with brood size in blue tit nests. The signs of these associations, negative and positive respectively, suggest that differences in brood size may indeed be involved in the interspecific difference found for these 2 ectoparasites. Large broods may better attract egg-laying blowflies through chemical or sound stimuli, as occurs with other bird-parasitic flies (Martínez-de la Puente et al., in press), while large broods may better resist mite attacks and delay mite population build-up (but see Burtt, Chow \& Babbitt, 1991). It is also possible that the different signs of the associations with brood size may be related to negative interspecific interactions between the 2 parasites (Merino \& Potti, 1995).

Bauchau (1998) has proposed that host interspecific differences in ectoparasite prevalence may be explained by differential exposure, differential resistance, or differential virulence. Immunological studies are needed to address resistance and virulence, something outside the scope of the present study. Differential exposure due to differences in nest composition was proposed by Bauchau (1998) as a 
possible factor underlying differences between sympatric avian hosts. Nests with different composition and structure could in some way induce differential attraction or survival of ectoparasites.

\section{INTRASPECIFIC DIFFERENCES IN ECTOPARASITE ABUNDANCE}

Intraspecific differences in parasite prevalence within the same region and habitat type have normally been attributed to host traits, including disease resistance ability, age, breeding cycle, and behavioural antiparasite mechanisms (Møller, 1997). However, it is known that different populations of hosts may experience large differences in ectoparasite infestation (e.g., Arriero et al., 2008). Variation in habitat structure and vegetation at the local scale could affect ectoparasite abundance through microclimatic variables (Arriero et al., 2008) or through availability of different plant materials for nest construction. We show that pied flycatchers experienced higher infestations in the locality where the preferred plant material (Cistus bark) for nests was not found. This suggests that the local difference in ectoparasite abundance might be due to differences in nest composition, a possibility that had never before been tested experimentally.

\section{NEST COMPOSITION AND ECTOPARASITE ABUNDANCE}

For mites, blowfly larvae, and fleas, nest composition could affect both microclimatic conditions for growth and mortality determined by plant secondary compounds. The evidence that pine bark in pied flycatcher nests may have insecticidal properties is reviewed in Bauchau (1998). According to Remes and Krist (2005), nest composition could affect demography of ectoparasite populations within nests driven by parameters like humidity (Heeb, Kölliker \& Richner, 2000) and/or attractiveness of different nest materials for laying females of ectoparasites. Our experimental results suggest that nest composition does not affect either active attraction by adults or ectoparasite demography within the nest. Prevalences in pied flycatcher nests were independent of nest type (constructed by blue tits or pied flycatchers), while prevalences in nests constructed by blue tits depended on host species for mites and blowflies. Thus, host interspecific differences in ectoparasite prevalences are probably related to factors other than nest composition. It is also clear that intraspecific differences in nest composition do not affect ectoparasite prevalences for pied flycatchers, so preferences for different materials may be unrelated to ectoparasitism. Finally, as expected from the lack of association of nest composition with ectoparasite presence, no effect of nest composition on reproductive success was detected for pied flycatchers.

\section{Acknowledgements}

J. Morales, G. Tomás, S. Ippi, and O. Gordo helped with field work in 2006. We thank J. Donés (Director of Montes de Valsaín) for permission to work in the study locality. The Junta de Castilla y León and Comunidad de Madrid authorized the ringing and handling of birds and the experimental manipulation. This study was funded by projects CGL2007-61251 (J. Moreno) and CGL2006-14129-C02-01 (S. Merino) from the Ministerio de Educación y Ciencia. J. Martínez-de la Puente, E. Lobato, S. del Cerro, and R. Ruiz-de-Castañeda were supported by grants from
El Ventorrillo-CSIC, MEC, Comunidad de Madrid, and JAE-CSIC, respectively. J. Rivero was not supported by any grant. This study is a contribution to the research developed at El Ventorrillo field station. This study complies with current Spanish laws.

\section{Literature cited}

Arriero, E., J. Moreno, S. Merino \& J. Martínez, 2008. Habitat effects on physiological stress response in nestling blue tits are mediated through parasitism. Physiological and Biochemical Zoology, 81: 195-203.

Bauchau, V., 1998. Comparison of parasitism level in two sympatric passerines: The pied flycatcher and the great tit. Écoscience, 5: 164-171.

Bennett, G. F. \& T. L. Whitworth, 1992. Host, nest, and ecological relationships of species of Protocalliphora (Diptera: Calliphoridae). Canadian Journal of Zoology, 70: 51-61.

Burtt, E. H., Jr., W. Chow \& G. A. Babbitt, 1991. Occurrence and demography of mites of tree swallow, house wren, and eastern bluebird nests. Pages 104-122 in J. E. Loye \& M. Zuk (eds.). Bird-Parasite Interactions: Ecology, Evolution and Behaviour. Oxford University Press, Oxford.

Carroll, J. F., 1994. Feeding deterrence of northern fowl mites (Acari: Macronyssidae) by some naturally occurring plant substances. Pesticide Sciences, 41: 203-207.

Collias, N. E. \& E. C. Collias, 1984. Nest Building and Bird Behavior. Princeton University Press, Princeton, New Jersey.

Cramp, S. \& C. M. Perrins, 1993. The Birds of the Western Palearctic. Volume VII. Oxford University Press, Oxford.

Del Hoyo, J., A. Elliott \& D. A. Christie, 2006. Handbook of the Birds of the World. Vol. 11. Lynx Edicions, Barcelona.

Del Hoyo, J., A. Elliott \& D. A. Christie, 2007. Handbook of the Birds of the World. Vol. 12. Lynx Edicions, Barcelona.

Eeva, T., E. Lehikoinen \& J. Nurmi, 1994. Effects of ectoparasites on breeding success of great tits (Parus major) and pied flycatchers (Ficedula hypoleuca) in an air pollution gradient. Canadian Journal of Zoology, 72: 624-635.

George, R. S., 1959. Fleas from nests of the pied flycatcher and other species in the forest of Dean. British Birds, 6: 132-136.

González-Mora, D. \& S. V. Peris, 1988. Los Calliphoridae de España: 1: Rhiniinae y Chrysomyinae (Diptera). Eos, 64: 91-139.

Hansell, M., 2000. Bird Nests and Construction Behaviour. Cambridge University Press, Cambridge.

Harper, G. H., A. Marchant \& D. G. Boddington, 1992. The ecology of the hen flea Ceratophyllus gallinae and the moorhen flea Dasypsyllus gallinulae in nest boxes. Journal of Animal Ecology, 61: 317-327.

Heeb, P., M. Kölliker \& H. Richner, 2000. Bird-ectoparasite interactions, nest humidity, and ectoparasite community structure. Ecology, 81: 958-968.

Jacobson, M., 1990. Glossary of Plant-Derived Insect Deterrents. CRC Press, Boca Raton, Florida.

Martínez-de la Puente, J., S. Merino, E. Lobato, J. Rivero-de Aguilar, S. del Cerro, R. Ruiz-de Castañeda \& J. Moreno, in press. Does weather affect biting fly abundance in avian nests? Journal of Avian Biology.

Mazgajski, T. D., 2007. Effect of old nest material on nest site selection and breeding parameters in secondary hole nesters A review. Acta Ornithologica, 42: 1-14.

Merino, S., 1993. Efectos del ectoparasitismo en el Papamoscas Cerrojillo Ficedula hypoleuca. M.Sc. thesis. Universidad. de Alcalá de Henares, Madrid. 
Merino, S. \& J. Potti, 1995. Mites and blowflies decrease growth and survival in nestling pied flycatchers. Oikos, 73: 95-103.

Merino, S. \& J. Potti, 1996. Weather dependent effects of nest ectoparasites on their bird hosts. Ecography, 19: 107-113.

Møller, A. P., 1997. Parasitism and the evolution of host life history. Pages 105-127 in D. H. Clayton \& J. Moore (eds.). Host-Parasite Evolution: General Principles and Avian Models. Oxford University Press, Oxford.

Moreno, J., E. Lobato, J. Morales, S. Merino, J. Martínez-de la Puente \& G. Tomás, 2008a. Pre-laying nutrition mediates maternal effects on offspring immune capacity and growth in the pied flycatcher. Oecologia, 156: 727-735.

Moreno, J., J. Martínez, C. Corral, E. Lobato, S. Merino, J. Morales, J. Martínez-de la Puente \& G. Tomás, 2008b. Nest construction rate and stress in female pied flycatchers Ficedula hypoleuca. Acta Ornithologica, 43: 57-64.

Moss, W. W., 1978. The mite genus Dermanyssus: A survey, with description of Dermanyssus trochilinis, n. sp., and a revised key to the species (Acari : mesostigmata : Dermanyssidae). Journal of Medical Entomology, 14: 627-640.
Oppliger, A., H. Richner \& P. Christe, 1994. Effect of an ectoparasite on lay date, nest-site choice, and hatching success in the great tit (Parus major). Behavioral Ecology, 5: 130-134.

Puchala, P., 2004. Detrimental effects of larval blow flies (Protocalliphora azurea) on nestlings and breeding success of Tree Sparrows (Passer montanus). Canadian Journal of Zoology, 82: 1285-1290.

Remes, V. \& M. Krist, 2005. Nest design and the abundance of parasitic Protocalliphora blow flies in two hole-nesting passerines. Écoscience, 12: 549-553.

Rendell, W. B. \& N. A. M. Verbeek, 1996. Are avian ectoparasites more numerous in nest boxes with old nest material? Canadian Journal of Zoology, 74: 1819-1825.

Tomás, G., S. Merino, J. Moreno \& J. Morales, 2007. Consequences of nest reuse for parasite burden and female health and condition in blue tits, Cyanistes caeruleus. Animal Behaviour, 73: 805-814.

Tripet, F. \& H. Richner, 1997. The coevolutionary potential of a 'generalist' parasite, the hen flea Ceratophyllus gallinae. Parasitology, 115: 419-427. 